\title{
BIOACTIVE COMPONENTS AND ANTIOXIDANT, ANTIPROLIFERATIVE, AND ANTIHYPERGLYCEMIC ACTIVITIES OF WILD CORNELIAN CHERRY (CORNUS MAS L.)
}

\author{
Božana Odžaković ${ }^{*}$, Pero Sailović1, Darko Bodroža ${ }^{1}$, Vesna Kojićc ${ }^{2}$, \\ Dimitar Jakimov², Zoran Kukrić ${ }^{1}$ \\ ${ }^{1}$ University of Banja Luka, Faculty of Technology, Bulevar vojvode Stepe Stepanovića 73, \\ 78000 Banja Luka, Republic of Srpska, Bosnia and Herzegovina \\ ${ }^{2}$ Oncology Institute of Vojvodina, Faculty of Medicine, University of Novi Sad, Put Dr Goldmana 4, \\ 21204, Sremska Kamenica, Serbia \\ bozana.odzakovic@tf.unibl.org
}

The contents of polyphenolic components (total polyphenols, flavonoids, and monomeric anthocyanins) and vitamin $\mathrm{C}$, and the bioactive potential (antioxidant, antiproliferative, and antihyperglycemic activities) of wild cornelian cherry were determined. Samples were collected from four different locations in Bosnia and Herzegovina. Sample $\mathrm{CC}_{3}$ from Drinić had the highest monomeric anthocyanin content $(1.40 \mathrm{mg} \mathrm{CyGE} / \mathrm{g} \mathrm{FW})$ and the highest inhibition of free radicals $\left(\mathrm{IC}_{50}{ }^{\mathrm{DPH}}=262.19 \mathrm{mg} / \mathrm{ml} ; \mathrm{IC}_{50}{ }^{\mathrm{ABTS}}=\right.$ $\left.76.78 \mathrm{mg} / \mathrm{ml} ; \mathrm{IC}_{50} \mathrm{OH}^{*}=102.31 \mathrm{mg} / \mathrm{ml}\right)$ and inhibition of breast adenocarcinoma cell line growth $\left(\mathrm{IC}_{50}{ }^{\mathrm{MCF}-7}\right.$ $=1.37 \mathrm{mg} / \mathrm{ml})$. Sample $\mathrm{CC}_{4}$ from Drvar showed the highest total polyphenol (55.92 mg GAE/g DW) and vitamin $\mathrm{C}(88.74 \mathrm{mg} / \mathrm{g} \mathrm{FW})$ contents. Sample $\mathrm{CC}_{4}$ significantly inhibited the growth of cervix epithelioid carcinoma $\left(\mathrm{IC}_{50}{ }^{\mathrm{HeLa}}=0.62 \mathrm{mg} / \mathrm{ml}\right)$ and lung adenocarcinoma $\left(\mathrm{IC}_{50}{ }^{\mathrm{A} 549}=0.48 \mathrm{mg} / \mathrm{ml}\right)$ cell lines, and $\alpha$ glucosidase $\left(\mathrm{IC}_{50}{ }^{\mathrm{AGHA}}=0.466 \mathrm{mg} / \mathrm{ml}\right)$. Wild cornelian cherry could be used as a functional food with beneficial pro-health properties.

Key words: cornelian cherry; polyphenolic compound; vitamin C; bioactivity

\section{БИОАКТИВНИ КОМПОНЕНТИ И АНТИОКСИДАЦИСКО, АНТИПРОЛИФЕРАТИВНО И АНТИХИПЕРГЛИКЕМИЧНО ДЕЈСТВО НА ДРЕНКИ (CORNUS MAS L.)}

Определена е содржината на полифенолни состојки (вкупни полифеноли, флавоноиди и мономерни антицијани) и витамин $\mathrm{C}$, како и биоактивниот потенцијал (антиоксидациското, антипролиферативното и антигликемичното дејство) на дренки. Примероците беа собрани од различни локации во Босна и Херцеговина. Примерокот $\mathrm{CC}_{3}$ од Дриниќ имаше најголема содржина на мономерен антоцијанин $(1,40 \mathrm{mg} C \mathrm{CGE} / \mathrm{g} \mathrm{FW})$ и највисока инхибиција на слободни радикали $\left(\mathrm{IC}_{50}{ }^{\mathrm{DPPH}}=262,19 \mathrm{mg} / \mathrm{ml} ; \mathrm{IC}_{50}{ }^{\mathrm{ABTS}}=76,78 \mathrm{mg} / \mathrm{ml} ; \mathrm{IC}_{50}{ }^{\mathrm{OH}^{*}}=102,31 \mathrm{mg} / \mathrm{ml}\right)$ како и инхибиција врз растот на клетки на аденокарцином на дојка $\left(\mathrm{IC}_{50}{ }^{\text {MCF-7 }}=1,37 \mathrm{mg} / \mathrm{ml}\right)$. Примерокот $\mathrm{CC}_{4}$ од Дрвар покажа највисока содржина на полифеноли (55,92 mg GAE/g DW) и на витамин C $(88,74 \mathrm{mg} / \mathrm{g} \mathrm{FW})$. Примерокот $\mathrm{CC}_{4}$ значително го спречуваше растот на цервикалниот епителоиден карцином $\left(\mathrm{IC}_{50}{ }^{\mathrm{HeLa}}=0,62 \mathrm{mg} / \mathrm{ml}\right)$ и клетките од белодробниот аденокарцином $\left(\mathrm{IC}_{50}{ }^{\mathrm{A} 549}=\right.$ $0,48 \mathrm{mg} / \mathrm{mL}$, како и на $\alpha$-глукозидаза $\left(\mathrm{IC}_{50}{ }^{\mathrm{AGHA}}=0,466 \mathrm{mg} / \mathrm{ml}\right)$. Дренките можат да се користат како функционална храна со корисни здравствени својства.

Клучни зборови: дренка; полифенолни соединенија; витамин C; биоактивност 


\section{INTRODUCTION}

Wild fruits, especially berries, are good sources of various components such as biologically active substances. Recently, consumer interest in fruit has been growing due to its pleasant flavor and specific composition [1]. Cornelian cherry (Cornus mas L.) is the most important fruit of the family Cornaceae and grows mostly in the Balkan Peninsula, central Europe, and southwest Asia [2, 3]. Bosnia and Herzegovina is abundant in wild edible plants. Uncultivated cornelian cherry is widespread in this area and its use for the traditional production of beverages and jams dates back centuries. Many studies indicate the nutritional value and high content of polyphenolic components, organic acids, vitamins and other bioactive compounds in cornelian cherry fruit [4-7]. Vitamin $\mathrm{C}$ stimulates the immune system and protects the body from infection. It affects the increased number of lymphocytes important for the formation of antibodies. It is known for its antioxidant activity, keeping ferrous and cuprous ions levels low, and its preventive role in cardiovascular diseases, hypertension, and diabetes [4-7]. Phenolic compounds, as secondary metabolites of plants that protect plant cells against oxidative stress caused mainly by free radicals, are important in the human diet because of their antioxidant properties. All these compounds play a part in the wide range of biological activity of cornelian cherry fruits, such as their antimicrobial, antihyperglycemic, antiinflammatory, anti-atherosclerotic, antiproliferative, hepatoprotective, cardioprotective, and antioxidant activities [8-10]. Antioxidant activity is a substantial factor in the evaluation of the nutritional value of fruit and is influenced by the content of bioactive components and the mechanism and kinetics of their reactions [11, 12]. Therefore, different antioxidant assays, including DPPH, ABTS, FRAP, PRAC, $\mathrm{OH}^{\circ}$, and $\mathrm{NO}^{\circ}$ radical scavenging activities, are used for cornelian cherry [4-6]. An appropriate level of antioxidants in fruit reduces the risk of cancer. Studies performed in vitro and in vivo on different human cancer cell lines indicate the antiproliferative activity of cornelian cherry [13-15]. The inhibitory effect of cornelian cherry on the enzyme $\alpha$-glucosidase, responsible for the hydrolysis of carbohydrates, has been reported [2]. The aim of this study was to determine the contents of polyphenolic compounds and vitamin $\mathrm{C}$ in wild cornelian cherry from Bosnia and Herzegovina. In order to investigate the bioactivity of these samples, antioxidant, antiproliferative, and antihyperglycemic activities were determined. The possible contribution of the contents of biologically active compounds to the obtained effects was calculated by Pearson correlation.

\section{MATERIALS AND METHODS}

\subsection{Plant material}

Wild cornelian cherry (Cornus mas L.) fruit samples were collected at the beginning of September 2019 at the stage of full maturity from four different locations in Bosnia and Herzegovina $(\mathrm{B} \& \mathrm{H})$ :

- Ljubomir (sample $\mathrm{CC}_{1}$ : altitude: $666 \mathrm{~m}$; latitude: 4247'9.09"; longitude: 18²1'54.32"; average temperature: $15^{\circ} \mathrm{C}$; average precipitation: $1600 \mathrm{l} / \mathrm{m}^{2}$; average number of sunny days: 260 ).

- Koravlica (sample $\mathrm{CC}_{2}$ : altitude: $556 \mathrm{~m}$; latitude: $42^{\circ} 50^{\prime} 40.28^{\prime \prime}$; longitude: $18^{\circ} 28^{\prime} 16.29^{\prime \prime}$; average temperature: $13^{\circ} \mathrm{C}$; average precipitation: $1700 \mathrm{l} / \mathrm{m}^{2}$; average number of sunny days: 250 ).

- Drinić (sample $\mathrm{CC}_{3}$ : altitude: $559 \mathrm{~m}$; latitude: $44^{\circ} 21^{\prime} 53.75^{\prime \prime}$; longitude: $16^{\circ} 22^{\prime} 25.51^{\prime \prime}$; average temperature: $9^{\circ} \mathrm{C}$; average precipitation: $1350 \mathrm{l} / \mathrm{m}^{2}$; average number of sunny days: 150).

- Drvar (sample $\mathrm{CC}_{4}$ : altitude: $789 \mathrm{~m}$; lati-

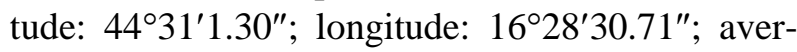
age temperature: $11^{\circ} \mathrm{C}$; average precipitation: $1100 \mathrm{l} / \mathrm{m}^{2}$; average number of sunny days: 160 ).

\subsection{Preparation of fruit extracts}

Sample extraction was performed according to the standard method described by Jazić et al. [16]. Samples were crushed and homogenized after removal of the stones from the fruits. Fruit samples $(200 \mathrm{~g})$ were extracted with $250 \mathrm{ml}$ of $80 \%$ ethanol (v/v) using a Soxhlet extractor. After $6 \mathrm{~h}$ of extraction, the samples were evaporated to dryness in a rotary vacuum evaporator at temperatures up to $50{ }^{\circ} \mathrm{C}$. The drying of the samples was continued in a vacuum desiccator for 7 days. The obtained extracts were kept at $-18{ }^{\circ} \mathrm{C}$ until analysis.

\subsection{Total polyphenol, flavonoid, and monomeric anthocyanin contents}

Content of polyphenolic compounds was measured by UV-vis spectrophotometry (Lambda 25, PerkinElmer, USA).

The total polyphenol content (TPC) of extracts was determined according to the FolinCiocalteu method, described by Orsavová et al. 
[12] with some modifications. Folin-Ciocalteu solution $(1.5 \mathrm{ml}$ of stock Folin-Ciocalteu solution dissolved with water at $1: 10$ ratio) and $1.5 \mathrm{ml}$ of $7.5 \% \mathrm{NaHCO}_{3}$ were added to $0.2 \mathrm{ml}$ of diluted extract. The mixture was kept for $30 \mathrm{~min}$ in the dark at room temperature, and the absorbance then measured at $765 \mathrm{~nm}$. The results were expressed as mg gallic acid equivalent per gram of dry extract (mg GAE/g DW) using a calibration curve $\left(y=0.0043 x-0.0295 ; \mathrm{R}^{2}=0.9993\right)$.

The total flavonoid content (TFC) was determined according to the method described by Ordoñez et al. [17]. A mixture of $2 \%$ ethanolic $\mathrm{AlCl}_{3}$ solution $(1 \mathrm{ml})$ and diluted extract $(1 \mathrm{ml})$ was kept for $30 \mathrm{~min}$ in the dark at room temperature. The absorbance was measured at $420 \mathrm{~nm}$.

The results were expressed as mg quercetin equivalent per gram of dry extract (mg QE/g DW) using a calibration curve $(y=0.0408 x-0.0339$; $\mathrm{R}^{2}=0.9981$ ).

Total monomeric anthocyanins content (TMAC) was determined by the $\mathrm{pH}$ differential method described by Popović et al. [6]. Sample $(10 \mathrm{~g})$ was extracted with $\mathrm{HCl} /$ ethanol $(85: 15 \%$ $\mathrm{v} / \mathrm{v})$ for $24 \mathrm{~h}$ at $0{ }^{\circ} \mathrm{C}$. The extract was filtered through filter paper and $0.5 \mathrm{ml}$ of extract was mixed with $9.5 \mathrm{ml}$ of $\mathrm{KCl}$ buffer, $\mathrm{pH} 1.0$ and $9.5 \mathrm{ml} \mathrm{NaOAc}$ buffer, $\mathrm{pH}$ 4.5. Absorbance was measured at $510 \mathrm{~nm}$ and $700 \mathrm{~nm}$ after $15 \mathrm{~min}$ incubation at room temperature. The absorbance was calculated as:

$$
A=\left(A_{510}-A_{700}\right) \mathrm{pH}_{1.0}-\left(A_{510}-A_{700}\right) \mathrm{pH}_{4.5} .
$$

The anthocyanin content of each fruit sample was calculated from the following equation:

$$
\mathrm{TMAC}=(A \times M \times \mathrm{DF} \times 100 / \varepsilon),
$$

where $A$ is absorbance, $M$ is the molecular weight ( $449.2 \mathrm{~g} / \mathrm{mol}), \mathrm{DF}$ is the dilution factor $(40), \varepsilon$ is the molar absorptivity of cyanidin-3-glucoside $(26,9001 / \mathrm{mol} \mathrm{cm})$. The results were expressed as mg cyanidin-3-glucoside equivalent per gram of fresh weight (mg CyGE/g FW).

\subsection{Vitamin C content}

Vitamin $\mathrm{C}$ was determined according to the EN 14130:2003 method and expressed as content of ascorbic acid (the sum of ascorbic acid and its oxidized form dehydroascorbic acid). The extraction of vitamin $\mathrm{C}$ from fresh fruit samples (within $24 \mathrm{~h}$ of harvesting the fruit) was performed using metaphosphoric acid solution. A reducing solution was used to transform dehydro-L(+) ascorbic acid to $\mathrm{L}(+)$ ascorbic acid. Homogenized sample $(10 \mathrm{~g})$ was extracted with $100 \mathrm{ml}$ of metaphosphoric acid $(20 \mathrm{~g} / \mathrm{l})$ and $20 \mathrm{ml}$ of the sample extract solution stabilized with $10 \mathrm{ml}$ of L-cysteine solution $(40 \mathrm{~g} / \mathrm{l})$. The $\mathrm{pH}$ was adjusted to $7.0-7.2$ by adding trisodium phosphate solution $(200 \mathrm{~g} / \mathrm{l})$ and stirring for exactly $5 \mathrm{~min}$. The $\mathrm{pH}$ was then reduced to $2.5-$ 2.8 by adding metaphosphoric acid solution $(200 \mathrm{~g} / \mathrm{l})$. The prepared samples were adjusted to a volume of $50 \mathrm{ml}$ with ultrapure water, homogenized, and filtered through $0.45-\mu \mathrm{m}$ syringe filters (Macherey-Nagel, $25 \mathrm{~mm} \times 0.45 \mu \mathrm{m}$, regenerated cellulose) into the vial. Vitamin $\mathrm{C}$ was determined by HPLC (Ultimate 3000, Dionex, Germering, Germany) with a PAD 3000 photodiode array detector and Ascentis RP Amide column $(5 \mu \mathrm{m}, 250$ $\times 4.6 \mathrm{~mm})$. Two mobile phases, solvent A $(50 \mathrm{mM}$ phosphoric acid) and B (methanol) were eluted in isocratic mode for $10 \mathrm{~min}$ for chromatographic separation. The prepared sample $(20 \mu \mathrm{l})$ was injected into the column at $25^{\circ} \mathrm{C}$. The time of analysis was $10 \mathrm{~min}$, the flow rate $1 \mathrm{ml} / \mathrm{min}$, and the chromatograms were registered at $245 \mathrm{~nm}$. The results were expressed as $\mathrm{mg}$ vitamin $\mathrm{C}$ per $100 \mathrm{~g}$ of fresh weight.

\subsection{HPLC analysis of individual polyphenolic compounds}

Identification and quantification of the polyphenolic compounds in the cornelian cherry extracts was performed by HPLC (Shimadzu Prominence, Shimadzu, Kyoto, Japan), consisting of an LC-20AT binary pump, CTO-20 A thermostat and SIL-20 A automatic dispenser connected to an SPD-20AV UV-vis detector. Chromatograms were recorded at different wavelengths for individual compounds: $280 \mathrm{~nm}$ for hydroxybenzoic acids, ellagic acid, catechin, and epicatechin, $320 \mathrm{~nm}$ for hydroxycinnamic acids, and $360 \mathrm{~nm}$ for flavonols. The separation was performed on a Luna C-18 RP column, $5 \mu \mathrm{m}, 250 \times 4.6 \mathrm{~mm}$ with a $\mathrm{C} 18$ guard column, $4 \times 30 \mathrm{~mm}$ (both from Phenomenex, Torrance, CA, USA). Two mobile phases, A (acetonitrile) and $\mathrm{B}$ (1\% formic acid) were used at flow rates of $1 \mathrm{ml} \mathrm{min}^{-1}$ with the following gradient profile: $0-10 \mathrm{~min}$ from 10 to $25 \% \mathrm{~B} ; 10-20 \mathrm{~min}$ linear increase up to $60 \% \mathrm{~B}$, and from $20 \mathrm{~min}$ to 30 min linear rise up to $70 \% \mathrm{~B}$, followed by $10 \mathrm{~min}$ return to initial $10 \% \mathrm{~B}$ with additional $5 \mathrm{~min}$ of equilibration time. Polyphenolic compounds were identified by matching the retention time and their spectral characteristics against those of standards. The external standard method was used for quantification. For each compound, a stock solution was 
made by weighing accurately standard commercial polyphenolic compounds followed by dissolution in $50 \%$ methanol. Solutions used for calibration were prepared by dilution of the stock solutions. Peak areas of chromatograms were plotted against known concentrations of standards. Equations generated via linear regression were used to establish concentrations of polyphenolic compounds in samples.

\subsection{Antioxidant activity determination}

\subsubsection{DPPH test}

For assessment of antioxidant activity of fruit extracts, evaluation of free radical scavenging effect on the 2,2-diphenyl-1-picrylhydrazyl (DPPH) radical was used, according to the method described by Liyana-Pathiranan and Shahidi [18]. DPPH solution in methanol $(1 \mathrm{ml}, 0.135 \mathrm{mM})$ was mixed with $1 \mathrm{~mL}$ of the sample (solution of extract in methanol at a concentration of $100-500 \mu \mathrm{g} / \mathrm{ml}$ ). After stirring, the reaction mixture was left in the dark at room temperature for $30 \mathrm{~min}$. The absorbance was measured at $515 \mathrm{~nm}$ by UV-vis spectrophotometry (Lambda 25, PerkinElmer, USA). The antioxidant activity of samples was quoted as $\mathrm{IC}_{50}(\mathrm{mg} / \mathrm{ml})$ and also as mmol Trolox equivalent per $100 \mathrm{~g}$ of dry extract (mmol TE/100 g DW) using a calibration curve $\left(y=8.0778 x+1.3959 ; R^{2}=0.9994\right)$.

\subsubsection{ABTS test}

The antioxidant activity of extracts was determinate by ABTS radical cation $\left(2,2^{\prime}\right.$-azinobis(3-ethylbenzothiazoline-6-sulfonic acid) decolorization assay [19]. ABTS stock solution was prepared freshly by reacting $7 \mathrm{mM}$ ABTS with $2.45 \mathrm{mM}$ potassium persulfate and storing in the dark at room temperature for $16 \mathrm{~h}$. The working solution was obtained by diluting the ABTS radical cation stock solution with methanol to obtain an absorbance of $0.7 \pm 0.02$ at $734 \mathrm{~nm}$. The working solution was mixed with $1 \mathrm{ml}$ of the sample (solution of extract in methanol at a concentration of $40-200 \mu \mathrm{g} / \mathrm{ml})$. After stirring, the reaction mixture was left in the dark at room temperature for $6 \mathrm{~min}$. The absorbance was measured at $734 \mathrm{~nm}$ by UVvis spectrophotometry (Lambda 25, PerkinElmer, USA). The antioxidant activity of samples was quoted $\mathrm{IC}_{50}$ value $(\mathrm{mg} / \mathrm{ml})$ and also as $\mathrm{mmol}$ Trolox equivalent per $100 \mathrm{~g}$ of dry extract (mmol TE/100 g DW) using a calibration curve $\left(y=18.039 x+0.1882 ; R^{2}=0.9977\right)$.

\subsubsection{OH radical neutralization}

The method described by Jazić et al. [16] was used for measuring 2-deoxy-D-ribose level degradation under the influence of hydroxyl radical. Hydroxyl radical solution (generated by mixing $10 \mathrm{mM} \mathrm{FeSO} 4,0.0147 \% \mathrm{H}_{2} \mathrm{O}_{2}, 0.05 \mathrm{M}$ deoxyribose and $0.067 \mathrm{M}$ phosphate buffer ( $\mathrm{pH}$ 7.4)) was mixed with $25 \mu \mathrm{l}$ of the sample (solution of extract in methanol at a concentration of $50-250 \mu \mathrm{g} / \mathrm{ml}$ ). Following incubation at $37{ }^{\circ} \mathrm{C}$ for $60 \mathrm{~min}$, $0.0372 \mathrm{~g} / \mathrm{ml}$ EDTA and $1.0 \mathrm{ml}$ TBA were added to the reaction mixture, which was then heated at 100 ${ }^{\circ} \mathrm{C}$ for $10 \mathrm{~min}$. The absorbance was measured at $532 \mathrm{~nm}$ by UV-vis spectrophotometry (Lambda 25, PerkinElmer, USA). The antioxidant activity of samples was shown as $\mathrm{IC}_{50}$ values $(\mathrm{mg} / \mathrm{ml})$ and also as mmol butylated hydroxytoluene equivalent per $100 \mathrm{~g}$ of dry extract (mmol BHTE/100 g DW) using a calibration curve $(y=1.131 x+16.879$; $R^{2}=0.9945$ ).

\subsection{Antiproliferative activity determination}

\subsubsection{Cell lines and samples preparation}

Colorimetric MTT assay was used for the determination of the antiproliferative activity of cornelian cherry extracts on human cancer cell lines (ATCC, USA): MCF-7 (breast adenocarcinoma), MDA-MB-231 (breast adenocarcinoma), HeLa (cervix epithelioid carcinoma) and A549 (lung adenocarcinoma). Cell lines were grown in a medium containing DMEM (PAA Laboratories $\mathrm{GmbH}$, Pashing, Austria) with $2 \mathrm{mM}$ glutamine, supplemented with $10 \%$ heat-inactivated fetal calf serum (PAA Laboratories $\mathrm{GmbH}$, Pashing, Austria), $100 \mathrm{IU} / \mathrm{ml}$ of penicillin, and $100 \mu \mathrm{g} / \mathrm{ml}$ of streptomycin (ICN Galenika, Belgrade, Serbia). All investigated cell lines were incubated at $37^{\circ} \mathrm{C}$ in culture flasks (Costar, $25 \mathrm{~cm}^{3}$ in an atmosphere of $100 \%$ humidity and $5 \% \mathrm{CO}_{2}$ (Heraeus), and subcultured twice per week. Single-cell suspensions were obtained using $0.5 \%$ trypsin (Serva, UK) with $0.1 \%$ EDTA-PBS.

Extracts were dissolved in distilled water and further diluted in DMEM, without fetal calf serum, to obtain five working concentrations (100$\left.2000 \mu \mathrm{g}_{\mathrm{dw}} / \mathrm{ml}\right)$. The final concentrations of extracts were obtained by mixing $10 \mu$ l solution of working concentration with $90 \mu \mathrm{l}$ of culture medium.

\subsubsection{MTT test}

Cell lines were harvested and seeded in quadruplicate 96-well microtiter plates at there 
were $5 \cdot 10^{3}$ cells in $90 \mu \mathrm{l}$ of medium. Plates with seeded cells were left in a thermostat at $37^{\circ} \mathrm{C}$, with $5 \% \mathrm{CO}_{2}$ for the next $24 \mathrm{~h}$. At the end of the incubation, $10 \mu \mathrm{l}$ of cornelian cherry extracts of appropriate concentration was added to all wells except the control (cells in the medium) and the incubation continued under the same conditions for $48 \mathrm{~h}$. The MTT solution ([2,5-diphenyltetrazolium bromide and 3-(4,5-dimethyl thiazolyl)], Sigma, USA), prepared immediately before addition, was added to all wells in the plate at $10 \mu \mathrm{l} / \mathrm{well}$ and incubation continued for the next $3 \mathrm{~h}$ (in a thermostat at $37{ }^{\circ} \mathrm{C}$, with $5 \% \mathrm{CO}_{2}$ ). After $3 \mathrm{~h}, 100 \mu \mathrm{l}$ of $0.04 \mathrm{M} \mathrm{HCl}$ in isopropanol was added to each well. The absorbance was read immediately after incubation on a microtiter plate reader (Multiscan, MCC/340, Fisher Scientific, Pittsburgh, USA) at a test wavelength of $540 \mathrm{~nm}$ and a reference wavelength of $690 \mathrm{~nm}$. The inhibition rates got measured in accordance with the following formula:

$$
\mathrm{RI}=\left(1-A_{\mathrm{s}} / A_{\mathrm{k}}\right) \times 100,
$$

where $\mathrm{RI}$ is rate of inhibition, $A_{\mathrm{s}}$ is the absorbance value of the sample with the extract, and $A_{\mathrm{k}}$ is the control sample's absorbance value.

The antiproliferative activity of samples was shown as $\mathrm{IC}_{50}$ values $(\mathrm{mg} / \mathrm{ml})$.

\subsection{Antihyperglycemic activity determination}

Antihyperglycemic activity (AHGA), presented as $\alpha$-glucosidase inhibitory potential, was determined using the method reported by Tumbas Šaponjac et al. [20], where each well contained $100 \mu \mathrm{l}$ of $2 \mathrm{mmol} / \mathrm{l}$ 4-nitrophenyl- $\alpha$-D-glucopyranoside in $10 \mathrm{mmol} / \mathrm{l}$ potassium phosphate buffer
(pH 7.0) and $20 \mu \mathrm{l}$ of the sample diluted in the buffer. The reaction was initiated by the addition of $100 \mu \mathrm{l}$ of the enzyme solution $(56.66 \mathrm{mU} / \mathrm{ml})$ and the plates incubated at $37^{\circ} \mathrm{C}$ for $10 \mathrm{~min}$. The absorbance of 4-nitrophenol released from 4nitrophenyl- $\alpha$-D-glucopyranoside at $405 \mathrm{~nm}$ was measured by UV-vis spectrophotometry (Lambda 25, PerkinElmer, USA). The antihyperglycemic activity is shown as $\mathrm{IC}_{50}$ value $(\mathrm{mg} / \mathrm{ml})$.

\subsection{Statistical analysis}

All measurements were carried out in triplicate and presented as mean value with standard deviation (SD). All results were subjected to a onefactor analysis of variance (ANOVA). Duncan's test was performed to estimate the significance of differences between mean values at $P<0.05$, using Statistica 12.0 software (StatSoft, Inc., Tulsa, OK, USA). The correlation coefficient was assessed by Pearson's correlation coefficient.

\section{RESULTS AND DISCUSSION}

\subsection{Determination of polyphenolic and vitamin $C$ contents}

Results of total polyphenols, total flavonoids, total monomeric anthocyanins, and vitamin $\mathrm{C}$ content in cornelian cherry fruit samples are presented in Table 1.

Sample $\mathrm{CC}_{4}$ showed statistically higher $(P \leq$ $0.05)$ TPC compared to other samples. The highest TMAC and vitamin $\mathrm{C}$ contents were in samples $\mathrm{CC}_{3}$ and $\mathrm{CC}_{4}$ with statistically significant differences $(P \leq 0.05)$ from samples $\mathrm{CC}_{1}$ and $\mathrm{CC}_{2}$.

Table 1

Content of total polyphenol, total flavonoid, total monomeric anthocyanin, and vitamin $C$ contents in cornelian cherry fruit extracts

\begin{tabular}{lcccc}
\hline \hline Sample & $\begin{array}{c}\text { TPC } \\
(\mathrm{mg} \mathrm{GAE} / \mathrm{g} \text { DW })\end{array}$ & $\begin{array}{c}\text { TFC } \\
(\mathrm{mg} \mathrm{QE} / \mathrm{g} \text { DW })\end{array}$ & $\begin{array}{c}\text { TMAC } \\
(\mathrm{mg} \mathrm{CyGE} / \mathrm{g} \mathrm{FW})\end{array}$ & $\begin{array}{c}\text { Vitamin C } \\
(\mathrm{mg} / 100 \mathrm{~g} \mathrm{FW})\end{array}$ \\
\hline $\mathrm{CC}_{1}$ & $49.84 \pm 1.76^{\mathrm{b}}$ & $1.47 \pm 0.01^{\mathrm{a}}$ & $0.89 \pm 0.01^{\mathrm{c}}$ & $50.33 \pm 1.56^{\mathrm{b}}$ \\
$\mathrm{CC}_{2}$ & $47.19 \pm 0.85^{\mathrm{b}}$ & $1.03 \pm 0.01^{\mathrm{d}}$ & $0.80 \pm 0.01^{\mathrm{d}}$ & $49.76 \pm 1.20^{\mathrm{b}}$ \\
$\mathrm{CC}_{3}$ & $50.27 \pm 0.19^{\mathrm{b}}$ & $1.21 \pm 0.01^{\mathrm{b}}$ & $1.40 \pm 0.06^{\mathrm{a}}$ & $87.44 \pm 3.28^{\mathrm{a}}$ \\
$\mathrm{CC}_{4}$ & $55.92 \pm 2.88^{\mathrm{a}}$ & $1.19 \pm 0.01^{\mathrm{c}}$ & $1.08 \pm 0.01^{\mathrm{b}}$ & $88.74 \pm 3.59^{\mathrm{a}}$ \\
\hline \hline
\end{tabular}

The results are expressed as mean value $(n=3) \pm \mathrm{SD}$.

Mean values with different superscript letters in the same column have a statistically

significant difference with $95 \%$ probability $(P<0.05)$.

TPC - total polyphenol content; TFC - total flavonoid content.

TMAC - total monomeric anthocyanin content. 
Higher TPC, TMAC, and vitamin $\mathrm{C}$ content were found in samples $\mathrm{CC}_{3}$ and $\mathrm{CC}_{4}$ from locations with lower average precipitation, lower average number of sunny days and lower average temperature relative to samples $\mathrm{CC}_{1}$ and $\mathrm{CC}_{2}$. Based on these results, it can be assumed that climatic conditions and the regions of growth affect the contents of these components in cornelian cherry. A similar conclusion was reached by Yilmaz et al. [23]. Unlike the TPC, TMAC, and vitamin $\mathrm{C}$ content, the TFC was the highest in sample $\mathrm{CC}_{1}$ and the lowest in sample $\mathrm{CC}_{2}$ (Table 1). Samples $\mathrm{CC}_{3}$ and $\mathrm{CC}_{4}$ had higher $(P \leq 0.05)$ TFCs than sample $\mathrm{CC}_{2}$ and lower $(P \leq 0.05)$ TFCs than sample $\mathrm{CC}_{1}$. The results are comparable to those obtained in cornelian cherry from Romania [11]. The TPCs of the investigated samples (Table 1) were lower than the TPC of cornelian cherry fruit from southeast Serbia [21]. A much lower TPC was found in cornelian cherry from Poland [22] and from northern Serbia [2, 6]. These differences can be explained by the use of different solvents and extraction conditions but also by genotypes, geographical region and environmental factors [23]. The differences in TMAC (Table 1) among cornelian cherry samples were significant $(P \leq 0.05)$. Similar values for the content of these components were obtained by Tural and Koca [24] and Hassanpour et al. [3]. The results of vitamin $\mathrm{C}$ content presented in Table 1 are similar to that in cornelian cherry from Montenegro obtained by Martinović and Cavoski [4]. Higher vitamin $\mathrm{C}$ content was found in cornelian cherry fruit from east Azerbaijan [3]. Cetkovská et al. [25] found that cornelian cherries from Azerbaijan, Greece, and Turkey were richer in vitamin $C$ than the same fruit from other countries, such as Serbia, Slovakia, and the Czech Republic.

\subsection{Determination of individual polyphenolic compounds}

Individual flavan-3-ols catechin and epicatechin were detected in relatively high levels in all cornelian cherry extracts (Table 2). Sample $\mathrm{CC}_{3}$ had significantly lower $(P \leq 0.05)$ content of epicatechin than other samples. The lowest content of catechin was found in sample $\mathrm{CC}_{2}$. Samples $\mathrm{CC}_{1}$ and $\mathrm{CC}_{2}$ had higher content of flavonoids (rutin) than phenolic acids, and samples $\mathrm{CC}_{3}$ and $\mathrm{CC}_{4}$ showed an opposite ratio. Samples $\mathrm{CC}_{3}$ and $\mathrm{CC}_{4}$ had higher total polyphenolic content (total-PC) than samples $\mathrm{CC}_{1}$ and $\mathrm{CC}_{2}$ (Table 2). Contents of ferulic and coumaric acids were significantly higher $(P \leq 0.05)$ in samples $\mathrm{CC}_{3}$ and $\mathrm{CC}_{4}$, while the contents of elagic acid were significantly higher $(P$ $\leq 0.05$ ) in samples $\mathrm{CC}_{1}$ and $\mathrm{CC}_{2}$. The highest contents of caffeic and chlorogenic acids were found in sample $\mathrm{CC}_{3}$. Contents of rutin and kaempferol were significantly higher $(P \leq 0.05)$ and the contents of quercetin significantly lower $(P \leq 0.05)$ in samples $\mathrm{CC}_{1}$ and $\mathrm{CC}_{2}$ compared to the other two samples. Drkenda et al. [26] found a significant influence of growing region on the contents of individual polyphenolic compounds.

Table 2

Content of individual phenolic compounds $(\mathrm{mg} / \mathrm{g} \mathrm{DW})$ in cornelian cherry fruit extracts identified and quantified by HPLC

\begin{tabular}{lcccc}
\hline \hline Compound & $\mathrm{CC}_{1}$ & $\mathrm{CC}_{2}$ & $\mathrm{CC}_{3}$ & $\mathrm{CC}_{4}$ \\
\hline Epicatechin & $0.960 \pm 0.039^{\mathrm{a}}$ & $0.946 \pm 0.041^{\mathrm{a}}$ & $0.557 \pm 0.019^{\mathrm{b}}$ & $0.962 \pm 0.042^{\mathrm{a}}$ \\
Catechin & $3.195 \pm 0.148^{\mathrm{a}}$ & $2.394 \pm 1.183^{\mathrm{a}}$ & $3.862 \pm 0.180^{\mathrm{a}}$ & $3.672 \pm 1.791^{\mathrm{a}}$ \\
Caffeic acid & $0.139 \pm 0.005^{\mathrm{a}}$ & $0.141 \pm 0.031^{\mathrm{a}}$ & $0.151 \pm 0.004^{\mathrm{a}}$ & $0.101 \pm 0.003^{\mathrm{b}}$ \\
Ferulic acid & $0.051 \pm 0.002^{\mathrm{c}}$ & $0.052 \pm 0.002^{\mathrm{c}}$ & $0.243 \pm 0.011^{\mathrm{a}}$ & $0.173 \pm 0.006^{\mathrm{b}}$ \\
Coumaric acid & $0.026 \pm 0.001^{\mathrm{c}}$ & $0.025 \pm 0.001^{\mathrm{c}}$ & $0.032 \pm 0.001^{\mathrm{b}}$ & $0.036 \pm 0.001^{\mathrm{a}}$ \\
Chlorogenic acid & $0.077 \pm 0.003^{\mathrm{b}}$ & $0.075 \pm 0.002^{\mathrm{b}}$ & $0.143 \pm 0.003^{\mathrm{a}}$ & $0.040 \pm 0.001^{\mathrm{c}}$ \\
Elagic acid & $0.053 \pm 0.001^{\mathrm{b}}$ & $0.081 \pm 0.003^{\mathrm{a}}$ & $0.022 \pm 0.001^{\mathrm{c}}$ & $0.010 \pm 0.001^{\mathrm{d}}$ \\
Rutin & $0.233 \pm 0.009^{\mathrm{b}}$ & $0.250 \pm 0.008^{\mathrm{a}}$ & $0.131 \pm 0.006^{\mathrm{c}}$ & $0.087 \pm 0.003^{\mathrm{d}}$ \\
Quercetin & $0.036 \pm 0.001^{\mathrm{c}}$ & $0.035 \pm 0.001^{\mathrm{c}}$ & $0.091 \pm 0.004^{\mathrm{a}}$ & $0.050 \pm 0.002^{\mathrm{b}}$ \\
Kaempferol & $0.111 \pm 0.005^{\mathrm{a}}$ & $0.113 \pm 0.004^{\mathrm{a}}$ & $0.012 \pm 0.004^{\mathrm{b}}$ & $0.007 \pm 0.001^{\mathrm{b}}$ \\
\hline Total-PC & 4.882 & 4.113 & 5.242 & 5.138 \\
\hline \hline
\end{tabular}

The results are expressed as mean $(n=3) \pm \mathrm{SD}$.

Mean values with different superscript letters in the same row have a statistically significant difference with $95 \%$ probability $(P<0.05)$.

Total-PC - total polyphenolic content. 
A similar relationship can be seen in this study, and it can be assumed that climatic conditions affect the content of individual polyphenolic compounds in cornelian cherry. Similar flavan-3ol, phenolic acid and flavonol profiles were described by Moldovan et al. [9]. Ellagic acid and kaempferol were detected at lower levels and coumaric acid in a similar range in results published by Blagojević et al. [2]. Quercetin was detected in the examined samples in contrast to results published by Blagojević et al. [2] for different genotypes of cornelian cherry from Serbia.

\subsection{Antioxidant activity}

The antioxidant activity of the four cornelian cherry fruit extracts was determined by three different methods: DPPH test, ABTS test and OH radical neutralization (Table 3).

All samples showed strong antioxidant activity. The results of antioxidant activity (DPPH test) were in a range similar to results obtained for cornelian cherry from Turkey [24], but higher compared to those from Serbia [2, 21]. Šamec and Piljac-Žegarac [27] obtained lower antioxidant activity (ABTS test) for cornelian cherry from northern Croatia, and Szczepaniak et al. [28] obtained higher antioxidant activity for cornelian cherry from Poland, compared to results obtained in this study. Antioxidant activity established by $\mathrm{OH}$ radical neutralization in this study is higher according to results presented by Popović et al. [6]. Sample $\mathrm{CC}_{3}$ showed significantly higher $(P \leq 0.05)$ antioxidant activity (DPPH, ABTS, and $\mathrm{OH}$ radicals) compared to other samples and had the highest chlorogenic acid, caffeic acid, and quercetin contents. The literature data shows that these phenolic compounds are the main active compounds and significantly influence the antioxidant properties of plant material [29].

\section{Table 3}

Antioxidant activity of cornelian cherry fruit extracts

\begin{tabular}{|c|c|c|c|c|c|c|}
\hline \multirow[t]{2}{*}{ Sample } & \multicolumn{3}{|c|}{$\mathrm{IC}_{50}(\mathrm{mg} / \mathrm{ml})$} & \multicolumn{2}{|c|}{$\begin{array}{c}\text { TE } \\
(\mathrm{mmol} / 100 \mathrm{~g} \mathrm{DW})\end{array}$} & \multirow{2}{*}{$\begin{array}{c}\begin{array}{c}\text { BHTE } \\
(\mathrm{mmol} / 100 \mathrm{~g} \mathrm{DW})\end{array} \\
\mathrm{OH}^{\cdot}\end{array}$} \\
\hline & DPPH & ABTS & $\mathrm{OH}^{\cdot}$ & DPPH & ABTS & \\
\hline $\mathrm{CC}_{1}$ & $289.83 \pm 4.3^{b}$ & $83.38 \pm 2.18^{c}$ & $183.21 \pm 6.58^{b}$ & $6.37 \pm 0.07^{\mathrm{a}}$ & $7.93 \pm 0.15^{\mathrm{d}}$ & $83.94 \pm 0.45^{\mathrm{a}}$ \\
\hline $\mathrm{CC}_{2}$ & $280.56 \pm 1.75^{\mathrm{c}}$ & $103.66 \pm 0.10^{b}$ & $201.50 \pm 5.33^{\mathrm{a}}$ & $6.14 \pm 0.03^{b}$ & $8.60 \pm 0.08^{c}$ & $83.97 \pm 0.40^{\mathrm{a}}$ \\
\hline $\mathrm{CC}_{3}$ & $262.19 \pm 3.82^{\mathrm{d}}$ & $76.78 \pm 2.10^{\mathrm{d}}$ & $102.31 \pm 4.24^{\mathrm{d}}$ & $6.36 \pm 0.07^{\mathrm{a}}$ & $9.44 \pm 0.19^{a}$ & $74.71 \pm 0.22^{\mathrm{b}}$ \\
\hline $\mathrm{CC}_{4}$ & $309.07 \pm 5.55^{\mathrm{a}}$ & $109.15 \pm 1.03^{\mathrm{a}}$ & $121.71 \pm 3.01^{\mathrm{c}}$ & $5.78 \pm 0.08^{\mathrm{c}}$ & $9.18 \pm 0.07^{\mathrm{b}}$ & $72.03 \pm 0.34^{\mathrm{c}}$ \\
\hline
\end{tabular}

The results are expressed as mean value $(n=3) \pm \mathrm{SD}$.

Mean values with different superscript letters in the same column indicate a statistically significant difference with $95 \%$ probability $(\mathrm{P}<0.05)$.

$\mathrm{OH}^{*}$ - hydroxyl radical; TE - Trolox equivalent (6-hydroxy-2,5,7,8-tetramethylchroman-2-carboxylic acid).

BHTE - butylated hydroxytoluene equivalent.

Very strong significant correlation $(P \leq 0.05)$ was found between DPPT test and $\mathrm{OH}$ radical neutralization $(r=0.978)$. Correlation between DPPH test and $\mathrm{OH}$ radical neutralization was strong $(\mathrm{r}=$ 0.683 ) and weak between ABTS test and $\mathrm{OH}$ radical neutralization $(r=0.132)$. Depending on the reaction system, antioxidants may act via multiple mechanisms or by a different single mechanism. No single antioxidant test can reflect precisely all antioxidants in a complex system because of multiple reaction characteristics and mechanisms [6].

\subsection{Antiproliferative and antihyperglycemic activity}

Results of antiproliferative and antihyperglycemic activity are presented in Table 4 . Extract
$\mathrm{CC}_{3}$ showed the strongest and $\mathrm{CC}_{2}$ statistically the weakest antiproliferative activity $(P \leq 0.05)$ toward the MCF-7 cell line. Extract $\mathrm{CC}_{4}$ showed the strongest activity toward the HeLa and A549 cell lines $(P \leq 0.05)$.

Extract $\mathrm{CC}_{1}$ had a lower $(P \leq 0.05) \mathrm{IC}_{50}$ for the MDA-MB-231 cell line in relation to other samples (Table 4), which indicates its stronger antiproliferative activity. To our knowledge, there are no data for the inhibition of MDA-MB-231 cell line proliferation by cornelian cherry. Lower $\mathrm{IC}_{50}$ values were obtained by Yousefi et al. [14] for the MCF-7 and A549 cell lines and by Blagojević et al. [30] for the MCF-7 cell line. The potential of cornelian cherry samples shown in this study for antiproliferative activity toward the MCF-7 cell line was higher than that obtained by Tiptiri- 
Kourpeti et al. [15]. Šavikin et al. [13] obtained strong antiproliferative activity toward the HeLa cell line (lower $\mathrm{IC}_{50}$ values) by cornelian cherry leaves and flowers. According to Šavikin et al. [13], ursolic and gallic acids show the highest activity against HeLa cells. The activity of ellagic acid and rutin was weaker than that of ursolic acid. The lowest contents of ellagic acid and rutin were found in the $\mathrm{CC}_{4}$ sample, which showed the high- est antiproliferative effect toward the HeLa cell line, which is in line with the results from other authors [13]. Studies indicate the connection between the contents of polyphenolic compounds such as total phenols, flavonoids, and anthocyanins and the antiproliferative activity of plant material [1]. Extracts $\mathrm{CC}_{3}$ and $\mathrm{CC}_{4}$ had the highest TPCs and TMACs, and $\mathrm{CC}_{1}$ the highest TFC, compared to other samples (Table 1).

T a ble 4

Antiproliferative and antihyperglycemic activity of cornelian cherry fruit extracts

\begin{tabular}{|c|c|c|c|c|c|}
\hline \multirow{3}{*}{ Sample } & \multicolumn{5}{|c|}{$\mathrm{IC}_{50}(\mathrm{mg} / \mathrm{ml})$} \\
\hline & \multicolumn{4}{|c|}{ Antiproliferative activity } & \multirow{2}{*}{$\begin{array}{l}\text { Antihyperglycemic } \\
\text { activity }\end{array}$} \\
\hline & MCF-7 & MDA-MB-231 & HeLa & A549 & \\
\hline $\mathrm{CC}_{1}$ & $1.97 \pm 0.09^{b}$ & $1.01 \pm 0.17^{\mathrm{b}}$ & $2.43 \pm 0.14^{\mathrm{a}}$ & $0.98 \pm 0.03^{\mathrm{b}}$ & $0.600 \pm 0.021^{b}$ \\
\hline $\mathrm{CC}_{2}$ & $17.71 \pm 2.37^{\mathrm{a}}$ & $1.42 \pm 0.09^{\mathrm{a}}$ & $0.67 \pm 0.03^{c}$ & $2.03 \pm 0.14^{\mathrm{a}}$ & $0.707 \pm 0.030^{\mathrm{a}}$ \\
\hline $\mathrm{CC}_{3}$ & $1.37 \pm 0.13^{\mathrm{b}}$ & $1.47 \pm 0.12^{\mathrm{a}}$ & $0.94 \pm 0.03^{\mathrm{b}}$ & $0.74 \pm 0.13^{c}$ & $0.570 \pm 0.019^{b}$ \\
\hline $\mathrm{CC}_{4}$ & $1.51 \pm 0.20^{\mathrm{b}}$ & $1.49 \pm 0.22^{\mathrm{a}}$ & $0.62 \pm 0.05^{\mathrm{c}}$ & $0.48 \pm 0.11^{\mathrm{d}}$ & $0.466 \pm 0.016^{\mathrm{c}}$ \\
\hline
\end{tabular}

The results are expressed as mean value $(n=3) \pm \mathrm{SD}$.

Mean values with different superscript letters in the same column indicate a statistically significant difference with $95 \%$ probability $(P<0.05)$.

Plant material with a high polyphenol content has a positive effect on the inhibition of $\alpha$ glucosidase, which is responsible for the breakdown of starch and disaccharides to glucose. Inhibition of $\alpha$-glucosidase in humans reduces blood glucose levels and protects the body from the risk of type 2 diabetes [31]. Extract $\mathrm{CC}_{4}$ showed the highest $(P \leq 0.05)$ antihyperglycemic activity compared to the other three extracts (Table 4). Higher $\alpha$-glucosidase inhibition of cornelian cherry from Serbia $\left(\mathrm{IC}_{50}=0.19-0.37 \mathrm{mg} / \mathrm{ml}\right)$ was obtained by Blagojević et al. [2]. Fruits, such as berries, rich in anthocyanins are known to be effective $\alpha$-glucosidase inhibitors. Results for the antihyperglycemic activity of cornelian cherry fruits in this study were in the range reported by Popović et al.
[1] for the antihyperglycemic activity of blackthorn fruits. In other studies, quercetin was found to be one of the strongest $\alpha$-glucosidase inhibitors [32, 33], and samples $\mathrm{CC}_{3}$ and $\mathrm{CC}_{4}$, with higher antihyperglycemic activities, had higher quercetin contents compared to samples $\mathrm{CC}_{1}$ and $\mathrm{CC}_{2}$, which is in line with literature data.

\subsection{Correlations}

The results of correlations (Pearson's correlation coefficient) between the content of polyphenolic compounds and bioactive effects of the investigated cornelian cherry samples are presented in Table 5.

Table 5

Correlations between contents of polyphenolic components and vitamin $C$ and antioxidant, antiproliferative, antihyperglycemic activities

\begin{tabular}{|c|c|c|c|c|c|c|c|c|}
\hline & $\mathrm{IC}_{50}{ }^{\mathrm{DPPH}}$ & $\mathrm{IC}_{50} \mathrm{ABTS}$ & $\mathrm{IC}_{50} \mathrm{OH}^{\cdot}$ & $\mathrm{IC}_{50}{ }^{\mathrm{MCF}-7}$ & 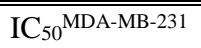 & $\overline{\mathrm{IC}} \mathrm{I}_{50} \mathrm{HeLa}$ & $\mathrm{IC}_{50}{ }^{\mathrm{A} 549}$ & $\overline{\mathrm{IC}_{50}{ }^{\mathrm{AHGA}}}$ \\
\hline TPC & 0.562 & 0.308 & $-0.598^{*}$ & $-\mathbf{0 . 5 9 3}^{*}$ & 0.173 & -0.227 & $-0.767^{*}$ & $-0.828^{*}$ \\
\hline TFC & 0.137 & -0.561 & -0.010 & $-0.685^{*}$ & $-0.706^{*}$ & $0.915^{*}$ & -0.488 & 0.270 \\
\hline TMAC & -0.431 & -0.503 & $-0.925^{*}$ & $-0.622^{*}$ & 0.398 & -0.249 & $-0.648^{*}$ & -0.508 \\
\hline Vitamin C & 0.025 & -0.008 & $-0.961^{*}$ & $-0.605^{*}$ & 0.510 & -0.510 & $-0.769^{*}$ & $-0.786^{*}$ \\
\hline
\end{tabular}

*Significant at $P \leq 0.05$.

Very strong $(r<-0.7)$, strong $(r<-0.5)$, moderate $(r<-0.3)$ and weak $(r>-0.3)$ correlations. 
TPC had strong $(r=-0.598)$ and TMAC had very strong correlation $(r=-0.925)$ with $\mathrm{OH}$ radical neutralization. Vitamin $\mathrm{C}$ content also had a very strong correlation $(r=-0.961)$ with antioxidant activity obtained by $\mathrm{OH}$ radical neutralization. Pantelidis et al. [5] found a similar correlation between hydroxyl radical inhibition and polyphenol and anthocyanin contents, but an opposite correlation with vitamin $\mathrm{C}$ content compared to this study. Antioxidant activity (ABTS test) were strongly, but not significantly $(P \geq 0.05)$ correlated with TFC $(r=$ $-0.561)$ and TMAC $(r=-0.503)$. An inverse correlation was found between antioxidant activity (DPPH test) and TPC $(r=0.562)$. A positive correlation between antioxidant activity and TPC has been reported by other authors $[3,6,21,25]$. Correlation between TMAC and DPPH test $(r=-0.431)$ was not significant $(P \geq 0.05)$, which is in accordance with the literature data [3]. Strong significant correlation $(P \leq 0.05)$ was found between cell growth inhibition (MCF-7) and phenolic compound and vitamin $\mathrm{C}$ contents (Table 5). A very strong correlation was seen between TFC and MDA-MB231 cell line inhibition $(r=-0.706)$. HeLa cell line inhibition was strongly, but not significantly $(P \geq$ $0.05)$, correlated $(r=-0.510)$ with vitamin $C$ content. An inverse correlation was found between the antiproliferative activity (HeLa cell line) and TFC ( $r$ $=0.915)$, which means that samples with lower TFCs had higher antiproliferative activity. Samples $\mathrm{CC}_{2}$ and $\mathrm{CC}_{4}$, with lower TFCs (Table 1), showed a stronger antiproliferative activity toward $\mathrm{HeLa}$ cell lines (Table 4) compared to samples $\mathrm{CC}_{1}$ and $\mathrm{CC}_{3}$ with higher TFCs. Antiproliferative activity (A549 cell lines) showed significant $(P \leq 0.05)$ correlation with TPC $(r=-0.767)$, TMAC $(r=-0.648)$ and vitamin $C$ content $(r=-0.769)$.

Very strong and significant $(P \leq 0.05)$ correlation was found between $\alpha$-glucosidase inhibition TPC $(r=-0.828)$ and vitamin C content $(r=-0.786)$, whereas $\alpha$-glucosidase inhibition was strongly but not significantly correlated with TMAC.

\section{CONCLUSIONS}

This investigation showed that the content of polyphenolic components and vitamin $\mathrm{C}$ varied among the samples from different growth locations. Results of the antioxidant, antiproliferative, and antihyperglycemic activity determination indicated the high bioactive potential of wild cornelian cherry. Pearson correlation coefficient values indicated a strong impact of total monomeric anthocyanin and vitamin $\mathrm{C}$ contents on $\mathrm{OH}$ radical neutralization. The growth inhibition of cell line MDAMB-231 was significantly influenced by the total flavonoid content, and the total polyphenol and vitamin C contents significantly affected the A549 cell line and $\alpha$-glucosidase inhibition. Wild cornelian cherry could be considered a good source of natural antioxidants with beneficial pro-health properties.

Acknowledgments. This study was supported financially by the Ministry of Scientific and Technological Development, Higher Education and Information Society, Republic of Srpska (19/6-020/961-75/18).

\section{REFERENCES}

[1] B. M. Popović, B. Blagojević, R. Ždero Pavlović, N. Mićić, S. Bijelić, B. Bogdanović, A. Mišan, M. M. D. Duarte, A. T. Sera, Comparison between polyphenol profile and bioactive response in blackthorn (Prunus spinosa L.) genotypes from north Serbia - from raw data to PCA analysis, Food Chem., 302, e125373 (2020). DOI: https://doi.org/10.1016/j.foodchem.2019.125373

[2] B. Blagojević, D. Agić, A. T. Serra, S. Matić, M. Matovina, S. Bijelić, B. M. Popović, An in vitro and in silico evaluation of bioactive potential of cornelian cherry (Cornus mas L.) extracts rich in polyphenols and iridoids, Food Chem., 335, e127619 (2021).

DOI: https://doi.org/10.1016/j.foodchem.2020.127619

[3] H. Hassanpour, Y. Hamidoghli, J. Hajilo, M. Adlipour, Antioxidant capacity and phytochemical properties of cornelian cherry (Cornus mas L.) genotypes in Iran, Sci. Hortic., 129, 459-463 (2011).

DOI: https://doi:10.1016/j.scienta.2011.04.017

[4] A. Martinović, I. Cavoski, The exploitation of cornelian cherry (Cornus mas L.) cultivars and genotypes from Montenegro as a source of natural bioactive compounds, Food Chem., 318, e126549 (2020). DOI: https://doi.org/10.1016/j.foodchem.2020.126549

[5] G. E, Pantelidis, M. Vasilakakis, G. A. Manganaris, G. Diamantidis, Antioxidant capacity, phenol, anthocyanin and ascorbic acid contents in raspberries, blackberries, red currants, gooseberries and cornelian cherries, Food Chem., 102, 777-783 (2007).

DOI: https://doi:10.1016/j.foodchem.2006.06.021

[6] B. M. Popović, D. Štajner, K. Slavko, B. Sandra, Antioxidant capacity of cornelian cherry (Cornus mas L.) Comparison between permanganate reducing antioxidant capacity and other antioxidant methods, Food Chem., 134, 734-741 (2012).

DOI: https://dx.doi.org/10.1016/j.foodchem.2012.02.170

[7] O. M. Szczepaniak, J. Kobus-Cisowska, W. Kusek, M. Przeor, Functional properties of cornelian cherry (Cornus mas L.): a comprehensive review. Eur. Food Res. Technol., 245, 2071-2087 (2019a).

DOI: https://doi.org/10.1007/s00217-019-03313-0

[8] B. Dinda, A. M. Kyriakopoulos, S. Dinda, V. Zoumpourlis, N. S. Thomaidis, A. Velegraki, C. Markopoulos, M. Dinda, Cornus mas L. (cornelian cherry), an important European and Asian traditional food and medicine: Ethnomedicine, phytochemistry and pharmacology for its commercial utilization in drug industry. J. Ethnopharm., 193, 670-690 (2016). DOI: https://doi.org/10.1016/j.jep.2016.09.042

[9] B. Moldovan, A. Filip, S. Clichici, R. Suharoschi, P. Bolfa, L. David, Antioxidant activity of cornelian cherry (Cornus mas L.) fruits extract and the in vivo evaluation of its anti- 
inflammatory effects, J. Funct. Foods, 26, 77-87 (2016). DOI: https://dx.doi.org/10.1016/j.jff.2016.07.004

[10] M. Kazimierski, J. Regula, M. Molska, Cornelian cherry (Cornus mas L.) - characteristics, nutritional and prohealth properties, Acta Sci. Pol. Technol. Aliment., 18 (1), 5-12 (2019)

DOI: https://dx.doi.org/10.17306/J.AFS.2019.0628

[11] S. Cosmulescu, I. Trandafir, V. Nour, Phenolic acids and flavonoids profiles of extracts from edible wild fruits and their antioxidant properties, Int. J. Food Prop., 20 (12), 3124-3134 (2017).

DOI:https://doi.org/10.1080/10942912.2016.1274906

[12] J. Orsavová, I. Hlaváčová, J. Mlček, L. Snopek, L. Mišurcová, Contribution of phenolic compounds, ascorbic acid and vitamin $\mathrm{E}$ to antioxidant activity of currant (Ribes L.) and gooseberry (Ribes uva-crispa L.) fruits, Food Chem., 284, 323-333 (2019). DOI: https://doi.org/10.1016/j.foodchem.2019.01.072

[13] K. Šavikin, G. Zdunić, T. Janković, T. Stanojković, Z Juranić, N. Menković, In vitro cytotoxic and antioxidative activity of Cornus mas and Cotinus coggygria, Nat. Prod. Res., 23 (18), 1731-1739 (2009). DOI: https://doi: 10.1080/14786410802267650

[14] B. Yousefi, M. Abasi, M. M. Abbasi, R. JahanbanEsfahlan, Anti-proliferative properties of Cornus mas fruit in different human cancer cells, Asian Pac. J. Cancer Prev., 16 (14), 5727-5731 (2015).

DOI: https://dx.doi.org/10.7314/APJCP.2015.16.14.5727

[15] A. Tiptiri-Kourpeti, E. Fitsiou, K. Spyridopoulou, S. Vasileiadis, C. Iliopoulos, A. Galanis, S. Vekiari, A. Pappa, K. Chlichlia, Evaluation of antioxidant and antiproliferative properties of Cornus mas L. fruit juice, $\mathrm{An}$ tioxidants, 8 (9), e377 (2019). DOI: https://doi.org/10.3390/antiox8090377

[16] M. Jazić, Z. Kukrić, J. Vulić, D. Četojević-Simin, Polyphenolic composition, antioxidant and antiproliferative effects of wild and cultivated blackberries (Rubus fruticosus L.) pomace, Int. J. Food Sci. Technol., 54, 194201 (2019). DOI: https://doi:10.1111/ijfs.13923

[17] A. A. L. Ordoñez, J. D. Gomez, M. A. Vattuone, M. I. Isla, Antioxidant activities of Sechium edule (Jacq.) Swartz extracts, Food Chem., 97 (3), 452-458(2006). DOI: https://doi:10.1016/j.foodchem.2005.05.024

[18] C. M. Liyana-Pathiranan, F. Shahidi, Antioxidant activity of commercial soft and hard wheat (Triticum aestivum L.) as affected by gastric $\mathrm{pH}$ conditions, J. Agric. Food Chem., 53, 2433-2440 (2005). DOI: https://doi:10.1021/jf049320i

[19] R. Re, N. Pellegrini, A. Proteggente, A. Pannala, M. Yang, C. Rice-Evans, Antioxidant activity applying an improved ABTS radical cation decolorization assay, Free Radic. Biol. Med., 26 (9-10), 1231-1237 (1999). DOI: https://doi.org/10.1016/S0891-5849(98)00315-3

[20] V. Tumbas Šaponjac, A. Girones-Vilaplana, S. Djilas, P. Mena, G. Ćetković, D. A. Moreno, J. Čanadanović Brunet, J. Vulić, S. Stajčić, M. Krunić, Anthocyanin profiles and biological properties of caneberry (Rubus spp.) press residues, J. Sci. Food Agric., 94, 2393-2400 (2014). DOI: https://doi: 10.1002/jsfa.6564

[21] A. S. Milenković-Andjelković, M. Z. Andjelković, A. N. Radovanović, B. C. Radovanović, V. Nikolić, Phenol composition, DPPH radical scavenging and antimicrobial activity of cornelian cherry (Cornus mas) fruit and leaf extracts, Hem. Ind., 69 (4), 331-337 (2015). DOI: https://doi: 10.2298/HEMIND140216046M
[22] A. Z. Kucharska, A. Sokół-Łẹtowska, N. Piórecki, Morphological, physical \& chemical, and antioxidant profiles of polish varieties of cornelian cherry fruit (Cornus mas L.), ZYWN-Nauk. Technol. Ja., 3 (76), 78-89 (2011). DOI: https://DOI: 10.15193/zntj/2011/76/078-089

[23] K. U. Yilmaz, S. Ercisli, Y. Zengin, M. Sengul, E. Y. Kafkas, Preliminary characterisation of cornelian cherry (Cornus mas L.) genotypes for their physico-chemical properties, Food Chem., 114, 408-412 (2009). DOI: https://doi:10.1016/j.foodchem.2008.09.055

[24] S. Tural, I. Koca, Physico-chemical and antioxidant properties of cornelian cherry fruits (Cornus mas L.) grown in Turkey, Sci. Hortic., 116, 362-366 (2008). DOI: https://doi:10.1016/j.scienta.2008.02.003

[25] J. Cetkovská, P. Diviš, M. Vespalcová, J. Pořízka, V. Řezníček, Basic nutritional properties of cornelian cherry (Cornus mas L.) cultivars grown in the Czech Republic, Acta Aliment., 44 (3), 357-364 (2015). DOI: https://doi: 10.1556/AAlim.2014.0013

[26] P. Drkenda, A. Spahić, A. Begić-Akagić, F. Gaši, A. Vranac, M. H. M. Blanke, Pomological characteristics of some autochthonous genotypes of cornelian cherry (Cornus mas L.) in Bosnia and Herzegovina, Erwerbsobstbau, 56 (2), 59-66 (2014). DOI: https://DOI 10.1007/s10341-014-0203-9

[27] D. Šamec, J. Piljac-Žegarac, Postharvest stability of antioxidant compounds in hawthorn and cornelian cherries at room and refrigerator temperatures-Comparison with blackberries, white and red grapes, Sci. Hortic., 131, 15-21 (2011). DOI: https://doi:10.1016/j.scienta.2011.09.021

[28] O. M. Szczepaniak, M. Ligaj, J. Kobus-Cisowska, P. Maciejewska, M. Tichoniuk, P. Szulc, Application for novel electrochemical screening of antioxidant potential and phytochemicals in Cornus mas extracts, CYTA-J. Food, 17 (1), 781-789 (2019b). DOI: https://doi: 10.1080/19476337.2019.1653378

[29] J. Lee, G. Park, Y. H. Chang, Nutraceuticals and antioxidant properties of Lonicera japonica Thunb. as affected by heating time, Int. J. Food Prop., 22 (1), 630-645 (2019). DOI: https://doi.org/10.1080/10942912.2019.1599389

[30] B. Blagojević, D. Četojević-Simin, F. Parisi, G. Lazzara, B. M. Popović Halloysite nanotubes as a carrier of cornelian cherry (Cornus mas L.) bioactives, LWT, 134, e110247 (2020). DOI: https://doi.org/10.1016/j.lwt.2020.110247

[31] P. Nowicka, A. Wojdyło, P. Laskowski, Inhibitory potential against digestive enzymes linked to obesity and type 2 diabetes and content of bioactive compounds in 20 cultivars of the peach fruit grown in Poland, Plant Foods Hum. Nutr., 7 (34), 314-320 (2018). DOI: https://doi.org/10.1007/s11130-018-0688-8.

[32] Q. You, F. Chen, X. Wang, Y. Jiang, S. Lin, Antidiabetic activities of phenolic compounds in muscadine against alpha-glucosidase and pancreatic lipase. $L W T$, 46, 164-168 (2012). DOI: https://doi.org/10.1016/j.lwt.2011.10.011

[33] C. Proença, M. Freitas, D. Ribeiro, E. F. T. Oliveira, J. L. C. Sousa, S. M. Tomé, M. J. Ramos, A. M. S. Silva, P. A. Fernandes, E. Fernandes, $\alpha$-Glucosidase inhibition by flavonoids: An in vitro and in silico structure-activity relationship study. J Enzyme Inhib Med Chem, 32,1216-1228 (2017).

DOI: https://doi.org/10.1080/14756 366.2017.1368503 